\title{
THE USE OF EDMODO AS A SOCIAL MEDIA TO SUPPORT THE ENHANCEMENTOF STUDENTS' PARAGRAPH WRITING SKILLS ON THE STUDENTS OF FIRST SEMESTER OF STKIP PANCASAKTI TANGERANG
}

\author{
Akhmad Subkhi Ramdhani \\ (Program studi Bahasa Inggris, Fakultas Keguruan dan Ilmu Pendidikan Universitas MH. Thamrin)
}

\begin{abstract}
ABSTRAK
Writing a paragraph academically is not an easy task; it consists of lengthy procedures and the ability to write skillfully. In addition, writing a paragraph academically is very important in academic life. However, in reality, many of the difficulties of writing a paragraph academically seen and have been proven by the students' writing test.

Thisresearch is aimed to explore the use of Edmodo as a media to enhance students' paragraph writing skills to promote the extensive learning at STKIP Pancasakti Tangerang.

The method used in this research is qualitative approach, and it applied Research and Development technique. In this case, the writer collected the data by using observation, structural interview, questionnaire and documentation. The interview was done for the students of first semester at STKIP Pancasakti Tangerang.

Based on the result of the research, it was found that there were several factors which influence students' inabilities to write an academic paragraph properly, they were students' writing ability was low or poor, time limitation, uncomfortable feeling in learning English, lack of motivation, lack of exposures, insufficient materials, and did not know how to start writing lack of feedback. In addition, it was also found that Edmodo had some features that could be used to solve those problems of the research, the problems of students in writing a paragraph academically. This research can be concluded that the use of Edmodo as a media to enhance students' paragraph writing skills to promote the extensive learning at STKIP Pancasakti Tangerang is useful. It is proven by several problems that hinder the teaching learning process are solved.
\end{abstract}

Key words: paragraph writing, social media, edmodo

\section{INTRODUCTION}

\section{Background of the Problems}

Writing, especially writing a paragraph academically is not an easy task. It needs study, practice, and exposure in order to make someone is able to write academically. Many of the difficulties of writing a paragraph academically have seen and been proven by students' writing test. Based on the data, it was found that the students had some difficulties in writing a paragraph academically, they are the term of developing the main idea, coherence, unity, sentence fragments, run on, comma splices, stringy, choppy, parallelism, organization, content, grammar (sentence problem), punctuation, and style and quality of expression (vocabulary). Therefore, in this research, the writer focused the major problem on the term of writing a paragraph academically.

Moreover, based on the data carried out by the writer, there were a lot of factors that caused the difficulties of students in writing a paragraph academically. For example, students had limited time in learning English, felt uncomfortable in learning English, not motivated to learn English, lack of exposures, had insufficient materials, did not know how to start writing, and lack of feedback. However, 
one of the biggest factors that caused them unable to write an academic paragraph properly was lack of exposure. Djonhar ${ }^{1}$ argues, "They have lack of exposure and insufficient opportunities to use a language actively." It seemed that the lack of exposure appeared because of the limited time in practicing their tasks; the time limitation made them less practice in writing and only received the materials, explanation and discussion in class only. Hence, they were lack of exposures. Basically, exposures were needed to keep them practicing what they had learnt and gave the stimulus to practice and discussed what they had learnt in the class.

In addition, there were some other reasons why students had lack of exposures in learning English, especially for writing. Herder \& King state many institutions writing program talk about the disproportion between how much times is spent on accuracy, fluency and complexity in current writing classrooms, yet almost of the teachers focus on the accuracy only. ${ }^{2}$ This focus could be understood due to the pressure on students, teachers and university; unfortunately, students stopped learning any English of particular value beyond the test itself. The decoding and translation skills that students acquired were only useful if students wished to become translators or English teachers themselves someday. The real shame was that the constant focused on accuracy leaved little time to focus on fluency or complexity.

This imbalance had two very detrimental outcomes. Firstly, many students lost confidence and motivation to make an effort studying English because of the overwhelming nature of the syllabus in university classes. Furthermore, students missed out on the natural opportunity to gain confidence and increased motivation that came with developing fluency in any skill, whether it be swimming, typing, playing the piano or writing.

Undeniably, writing a paragraph academically is not an easy task as it consists of lengthy procedures of conducting thorough study and the ability to write skillfully. Writing paragraph academically is very important in academic life because it is vital for growth and enhancement of important skills of someone in order to be able to lead his/her successful life after the completion of studies. Thus, academic writing is something that cannot be avoided as far as a student is a part teaching and learning process.

In contrast, many students still did not realize the importance of writing a paragraph academically and how it affected on their academic careers. There was no use avoiding writing academic papers or an essay as it had to be done throughout the academic careers. For example, a student who begins academic writing with a simple essay(s), and as he/she progresses to the higher academic levels of academic essay, writing becomes more difficult with times. However, it basically depends on the intellectual growth of the student himself.

In order to solve the problem of the research (how to enhance students' paragraph writing skills), researcher needed to find out the most suitable technique, method, and aid that could be applied effectively and efficiently for the students. Exposures and extensive learning had been chosen by the researcher to become the main strategies to solve the problems of the research. It was because writing a paragraph academically was something that must be learnt continuously, lot of exposures, study and practices; it was not anything that could be learnt instantly.

Nowadays, people around the world are getting easier in communicating to each other. It is because of the social networks which are getting enhanced. Moreover, McCarthy ${ }^{3}$ states, "The development and application of Web 2.0 technologies, such as blogs, online discussion boards, Flickr, YouTube, MySpace, Edmodo, and others, have increased in popularity in recent years."

\footnotetext{
${ }^{1}$ Shanty Ch. Djonhar. 2012. Introduction to Language Acquisition: The acquisition of English as a Foreign Language. Jakarta: Uhamka Press, P. 57-58.

${ }^{2}$ Herder S. \& King R. 2012. Extensive Writing: Another fluency approach for EFL learners. Extensive Reading World Congress Proceedings, P. 128-130

${ }^{3}$ J. McCarthy. 2012. International design collaboration and mentoring for tertiary students through Facebook. Australasian Journal of Educational Technology, 28(5), 755-775.http://www. ascilite.org.au/ajet/ajet28/ mccarthy.html(accessed April 20, 2013).
} 
Furthermore, because of the effectiveness, supremacy and the efficiency of social networks, the writer tried to find out the best social network that would be suitable for students to solve the problem of the research. Yet, the social network that would be chosen must be aimed and focused on learning language or education; it was not only for the effectiveness and efficiency, but also for the benefit and the ease of the learning language (English), especially in writing. The data informed that one of the social networks that amazingly increased which focused on education recently was Edmodo. Edmodo is a private social network available on internet which is deliberately intended for education.

The reasons why the writer chose Edmodo instead of other social media in this research were because of its supremacies. There were some social media that became the comparison between Edmodo and others in this research, they were Facebook, Moodle and Blog.

First is Edmodo vs. facebook. The writer did not choose facebook as his media to support the teaching learning process in this research because facebook allowed students to do cyber bullying. In addition, facebook bordered teacher in giving reflections to the students, for all the posts and comments must be seen by all members of the group. It was because in giving reflections, teacher should consider that students are different psychologically; some students had more sensitive feelings than others, and some were prefer to do the bullying. Moreover, facebook had big chance in distracting students' studiousness, for it had chatting feature. In short, facebook had some unsupported features as the supporting media in teaching learning process, especially in this research.

Next is Edmodo vs. Moodle. Edmodo is also different from Moodle because moodle is a media that is used for managing course system. If teacher requires a fully implemented course management system (CMS), he/she should consider using moodle or some similar tool. Yet, if a school still starting out on the e-learning or online journey - edmodo is an ideal starting place for a low-risk, low-cost entry point. With edmodo, a teacher is up and running in half-an-hour. While moodle takes significantly longer even if he/she has access to a web-based delivery service.

The last is the comparison of Edmodo's and Blog's features in supporting the teaching learning process, especially in writing skills. Blogs are different and complementary tools; edmodo is more about communicating with specific class and managing basic class activities, while in the school environment, blog are usually more about communicating with an external audience and showcasing work. An interesting take on this difference is to consider edmodo as a process tool - where the class discusses and develops ideas, and to view the class blog as a product delivery tool to show class work to the public. As pointed by Eileen Buescher", "Edmodo is an educational program that allows teachers and students to participate in micro blogging discussions, respond to polls, and manage and submit assignments." It promotes learning anytime and anyplace. Functionally, it allows teachers to post messages, discuss classroom topics, assign and grade class work, share content and materials, and network and exchange ideas with their peers.

\section{Research Problems}

In line with background of the problems above, below are the writer addresses the following research questions:

1. What factors do influence the students' inabilities to write an academic paragraph properly?

2. How is Edmodo used to solve the problem of limited time?

3. How is Edmodo used to improve students' motivation in writing paragraph academically?

4. How is Edmodo used to give exposures to students in writing paragraph academically?

5. How is Edmodo used to deliver feedback to students in writing paragraph academically?

${ }^{4}$ Eileen, Buescher. The Wonders of EducationalBlogging. 2010.http://coe.winthrop.edu/ jonesmg/LTI/2010Fwhitepapers/Eileen_Buescher.pdf (accessed April 24, 2013) 


\section{Objectives of the Study}

Given the formulation of the research questions, the objectives of this study are to investigate:

1. What factors do influence the students' inabilities to write an academic paragraph properly.

2. The way or method how Edmodo is used to solve the problem of limited time.

3. The way or method how Edmodo is used to improve students' motivation.

4. The way or method how Edmodo is used to give exposures to students.

5. The way or method how Edmodo is used to deliver feedback to students.

\section{Significances of the Study}

In accordance with the formulation of the research question, the results of this current study were expected to be benefit either for theoretically or practically.

1. Theoretically, the finding of this study was useful for improving or enhancing the use of Edmodo as a media to support the enhancement of students' paragraph writing skills to promote the extensive learning, so they have exposures as much as possible and be able to write a paragraph academically.

2. Practically, he finding of this study also could be useful for teachers to improve their teaching method and technique, for students, to enhance their motivation and promote autonomous learning in learning process, for institution, to improve its teachers' skills, its facilities, and its services, and for the researcher, to conduct the further research(s), particularly in the related area.

\section{Limitation of the Problems}

This research was focused on the strategy of how Edmodo as a media was used to support the enhancement of students' paragraph writing skills to promote the extensive learning.

\section{FRAME OF THEORIES}

This section discusses related literature that help and guide the writer to understand and to support the current study that is being investigated.

\section{Concept of Writing skill}

Many experts have defined writing in rather different words, but basically intended the same meaning, such as Harmer", "Writing is a form of communication to deliver thought or to express feeling through written form." In addition, for some experts, writing becomes the major concern in language skills. For instance, Clark and Ivanič ${ }^{6}$...there is no simple solution to know how to write: different people do it in different ways in different circumstances...it is not wrong to go backwards or forwards... the writing process is of its nature recursive.... On the other hand, the process of acquiring knowledge of how to learn writing is different for each person. Some people have the ability to acquire the knowledge faster and better than the others, and some people do not.

In sum, it can be said that writing is a support skill which is truly a difficult process to learn and a hard skill to teach. It involves being creative, spelling, grammar and punctuation, choice of appropriate words, sentence linking, and text construction. However, by uniting the sentences and all elements into an organized text, someone will be able to communicate and deliver his thoughts successfully.

\footnotetext{
5Jeremy Harmer. 2001. The Practice of English Language Teaching (3rd Edition). England: Longman, P.79

${ }^{6}$ Clark R. \& Ivanic R. 1991. Consciousness-raising about the writing process. In C. Candlin (Gen. Ed.), C. James \& P. Garrett (Eds.), Language awareness in the classroom. New York: Longman, Inc.
} 


\section{The objectives of Writing}

In finding the objectives of writing, the researcher looked up from several experts who tried to infer the objectives of writing. For example, Harmer" as stated before, "Writing is a form of communication that has function to deliver thought or to express feeling through written form." In addition to the previous, Jonah22 claims, "Writing can be used as an indirect means of communication to others to convey information."

Moreover, to get more detail definition of objectives of writing, the researcher also looked up to some universities, they are Ohio University and University of Central Arkansas (Uca). According to the Ohio University, it states that there are several writing skills learning objectives in the university:

1. Communicate efficiently in writing to a diversity of listeners and for a diversity of purposes.

2. Use writing as an instrument for thinking and learning

3. Develop skill in organizing writing and finishing tasks

4. Properly apply conventions of writing ${ }^{8}$

Moreover, Uca also gives its understanding toward the problem: the objectives of writing. Uca states that the general objective is to improve students' written expression of thought and ideas and provide learners occasions to explore ideas and to create connections between content areas. ${ }^{9}$ Furthermore, it states the written communication objectives for its students in completing the general education program.

\section{The concept of Paragraph Writing}

Writing a paragraph academically is not something that everyone can do. It needs a lot of practices and exposures, for in an academic paragraph there are some points that construct it. Oshima and Hogue ${ }^{10}$ argue

A paragraph is a basic unit of organization in writing in which a group of related sentences develops one main idea. It can be as short as one sentence or as long as ten sentences. The number of sentences is unimportant; however, it must be long enough to develop the main idea clearly, and it may stand by itself.

In addition, Lynn and Brizee ${ }^{11}$ also give their idea toward the discussion, they claim "a paragraph is a collection of related sentences dealing with a single topic, and to be as effective as possible, a paragraph should contain each of the following terms: unity, coherence, a topic sentence, and adequate development".

Furthermore, Gorrell ${ }^{12}$ claims "A paragraph is a group of related sentences marked with beginning indention." A paragraph has no exact length and no required number of sentences, they do conventionally have three characteristics: unified, coherent, and adequately developed. That is, a paragraph has a single thought, and all its parts are clearly related and supported to one another, also its point is sufficiently supported by details, examples, or explanations.

\footnotetext{
${ }^{7}$ Harmer, loc.cit.

${ }^{8}$ Ohio University. 2007. Learning Objectives: Writing skills learning Objectives. http:// www.ohio.edu/learningobjectives/ge_english_comp.html (accessed July 02, 2014).

${ }^{9}$ University of Central Arkansas. 2014. Objectives For The Skills. http://uca.edu/ gened/objectives-forthe-skills/ (accessed July 02, 2014).

${ }^{10}$ Alice Oshima \& Ann Hogue. 1991.Writing Academic English, Third Edition. New York: LONGMAN. P. 16.

${ }^{11}$ D. Lynn \& A. Brizee. 2013. On Paragraphs.http://owl.english.purdue.edu/ (accessed June 05, 2013).

${ }^{12}$ Gorrell. 2007. The Little, Brown Workbook. Longman. www.monmouth.edu/uploaded Files/Resources. (Accessed July 02, 2014).
} 
In accordance to the theories above, Walter argues that an academic paragraph has outlines that construct the paragraph itself, they are a topic sentence, body sentences, and concluding sentence. ${ }^{13}$ Moreover, there are also other aspects of writing in academic paragraph which discussed in this research. Brown and Bailey ${ }^{14}$ "Design an analytical scoring scale that specify five major categories and a description of five different levels in each category, ranging from unacceptable to excellent". The explanation of those categories could be seen in table 2.1

Table 2.1 Aspects of Writing in Academic Paragraph

\begin{tabular}{|c|c|c|c|c|c|}
\hline & $\begin{array}{l}20-18 \\
\text { Excellent to } \\
\text { good }\end{array}$ & $\begin{array}{l}17-15 \\
\text { Good to } \\
\text { adequate }\end{array}$ & $\begin{array}{l}14-12 \\
\text { Adequate to } \\
\text { fair }\end{array}$ & $\begin{array}{l}11-6 \\
\text { Unacceptable }\end{array}$ & $\begin{array}{l}5-1 \\
\text { Not college- } \\
\text { level work }\end{array}$ \\
\hline $\begin{array}{l}1 . \\
\text { Organiz } \\
\text { ation: } \\
\text { Introduc } \\
\text { tion, } \\
\text { body, } \\
\text { and } \\
\text { conclusi } \\
\text { on. }\end{array}$ & $\begin{array}{l}\text { Appropriate } \\
\text { title, effective } \\
\text { introductory } \\
\text { paragraph, } \\
\text { topic is stated, } \\
\text { leads to body; } \\
\text { transitional } \\
\text { expression } \\
\text { used; } \\
\text { arrangement of } \\
\text { materials shows } \\
\text { plan; supporting } \\
\text { evidence given } \\
\text { for } \\
\text { generalizations; } \\
\text { conclusion } \\
\text { logical and } \\
\text { complete }\end{array}$ & $\begin{array}{l}\text { Adequate title, } \\
\text { introduction, } \\
\text { and conclusion; } \\
\text { body of essay is } \\
\text { acceptable, but } \\
\text { some evidences } \\
\text { may be lacking, } \\
\text { some ideas are } \\
\text { not fully } \\
\text { developed; } \\
\text { sequence is } \\
\text { logical, but } \\
\text { transitional } \\
\text { expression may } \\
\text { be absent or } \\
\text { misused }\end{array}$ & $\begin{array}{l}\text { Mediocre or } \\
\text { scant } \\
\text { introduction } \\
\text { or } \\
\text { conclusion; } \\
\text { problems } \\
\text { with the } \\
\text { order of } \\
\text { ideas in } \\
\text { body; the } \\
\text { generalizatio } \\
\text { ns may not } \\
\text { be fully } \\
\text { supported by } \\
\text { the evidence } \\
\text { given; } \\
\text { problems of } \\
\text { organization } \\
\text { interfere }\end{array}$ & $\begin{array}{l}\text { Shaky or } \\
\text { minimally } \\
\text { recognizable } \\
\text { introduction; } \\
\text { organization } \\
\text { can barely be } \\
\text { seen; severe } \\
\text { problems with } \\
\text { ordering of } \\
\text { ideas; lack of } \\
\text { supporting } \\
\text { evidence; } \\
\text { conclusion } \\
\text { weak } \\
\text { illogical; or } \\
\text { inadequate } \\
\text { effort } \\
\text { organization }\end{array}$ & $\begin{array}{l}\text { Absence of } \\
\text { introduction } \\
\text { or } \\
\text { conclusion; } \\
\text { no apparent } \\
\text { organization } \\
\text { of body; } \\
\text { sever lack of } \\
\text { supporting } \\
\text { evidence; } \\
\text { writer has } \\
\text { not made } \\
\text { any effort to } \\
\text { organize the } \\
\text { composition }\end{array}$ \\
\hline $\begin{array}{l}2 . \\
\text { Logical } \\
\text { develop } \\
\text { ment of } \\
\text { ideas: } \\
\text { Content }\end{array}$ & $\begin{array}{l}\text { Essay addresses } \\
\text { the assigned } \\
\text { topic; the ideas } \\
\text { are concrete } \\
\text { and thoroughly } \\
\text { developed; no } \\
\text { extraneous } \\
\text { material; essay } \\
\text { reflects thought }\end{array}$ & $\begin{array}{l}\text { Essay addresses } \\
\text { the issues but } \\
\text { misses some } \\
\text { points; ideas } \\
\text { could be more } \\
\text { fully } \\
\text { developed; } \\
\text { some } \\
\text { extraneous } \\
\text { material is } \\
\text { present }\end{array}$ & $\begin{array}{l}\text { Developmen } \\
\text { t of ideas not } \\
\text { complete or } \\
\text { essay is } \\
\text { somewhat } \\
\text { off the topic; } \\
\text { paragraphs } \\
\text { are not } \\
\text { divided } \\
\text { exactly right }\end{array}$ & $\begin{array}{l}\text { Ideas } \\
\text { incomplete; } \\
\text { essay does not } \\
\text { reflect careful } \\
\text { thinking or was } \\
\text { hurriedly } \\
\text { written; } \\
\text { inadequate } \\
\text { effort in area of } \\
\text { content }\end{array}$ & $\begin{array}{l}\text { Essay is } \\
\text { completely } \\
\text { inadequate } \\
\text { and does not } \\
\text { reflect } \\
\text { college-level } \\
\text { work; no } \\
\text { apparent } \\
\text { effort to } \\
\text { consider the } \\
\text { topic } \\
\text { carefully }\end{array}$ \\
\hline $\begin{array}{l}\text { 3.Gram } \\
\text { mar }\end{array}$ & $\begin{array}{l}\text { Native-like } \\
\text { fluency in } \\
\text { English } \\
\text { grammar; } \\
\text { correct use of } \\
\text { relative clauses, } \\
\text { prepositions, } \\
\text { modals, } \\
\text { articles, verb } \\
\text { forms, and } \\
\text { tense } \\
\text { sequencing; no } \\
\text { fragments or } \\
\text { run-on } \\
\text { sentences }\end{array}$ & $\begin{array}{l}\text { Advance } \\
\text { proficiency in } \\
\text { English } \\
\text { grammar; some } \\
\text { grammar } \\
\text { problems do } \\
\text { not influence } \\
\text { communication } \\
\text {, although the } \\
\text { readers are } \\
\text { aware of them; } \\
\text { no fragments or } \\
\text { run-on } \\
\text { sentences }\end{array}$ & $\begin{array}{l}\text { Ideas are } \\
\text { getting } \\
\text { through to } \\
\text { the reader, } \\
\text { but grammar } \\
\text { problems are } \\
\text { apparent and } \\
\text { have a } \\
\text { negative } \\
\text { effect on } \\
\text { communicati } \\
\text { on; run-on } \\
\text { sentences or } \\
\text { fragments } \\
\text { present }\end{array}$ & $\begin{array}{l}\text { Numerous } \\
\text { serious } \\
\text { grammar } \\
\text { problems } \\
\text { interfere with } \\
\text { communication } \\
\text { of the writer's } \\
\text { ideas; grammar } \\
\text { review of some } \\
\text { areas clearly } \\
\text { needed; } \\
\text { difficult to read } \\
\text { sentences }\end{array}$ & $\begin{array}{l}\text { Severe } \\
\text { grammar } \\
\text { problems } \\
\text { interfere } \\
\text { greatly with } \\
\text { the message; } \\
\text { reader } \\
\text { cannot } \\
\text { understand } \\
\text { what the } \\
\text { writer was } \\
\text { trying to say; } \\
\text { unintelligibl } \\
\text { e sentence } \\
\text { structure }\end{array}$ \\
\hline
\end{tabular}

${ }^{13}$ F. Scott Walters. 2000. http://lrs.ed.uiuc.edu/students/fwalters/para.html. (Accessed October 18, 2013).

${ }^{14}$ Brown \& Bailey, Loc.cit. 


\begin{tabular}{|c|c|c|c|c|c|}
\hline $\begin{array}{l}\text { 4.Punctu } \\
\text { ation, } \\
\text { spelling, } \\
\text { and } \\
\text { mechani } \\
\text { cs }\end{array}$ & $\begin{array}{l}\text { Correct use of } \\
\text { English writing } \\
\text { conventions: } \\
\text { left and right } \\
\text { margins, all } \\
\text { needed capitals, } \\
\text { paragraphs } \\
\text { intended, } \\
\text { punctuation and } \\
\text { spelling; very } \\
\text { neat }\end{array}$ & $\begin{array}{l}\text { Some problems } \\
\text { with writing } \\
\text { conventions or } \\
\text { punctuation; } \\
\text { occasional } \\
\text { spelling errors; } \\
\text { left margin } \\
\text { correct; paper is } \\
\text { neat and legible }\end{array}$ & $\begin{array}{l}\text { Uses general } \\
\text { writing } \\
\text { convention } \\
\text { but has } \\
\text { errors; } \\
\text { spelling } \\
\text { problems } \\
\text { distract } \\
\text { readers; } \\
\text { punctuation } \\
\text { errors } \\
\text { interfere } \\
\text { with ideas }\end{array}$ & $\begin{array}{l}\text { Serious } \\
\text { problems with } \\
\text { format of } \\
\text { paper; part of } \\
\text { essay not } \\
\text { legible; errors } \\
\text { in sentence } \\
\text { punctuation and } \\
\text { final } \\
\text { punctuation; } \\
\text { unacceptable to } \\
\text { educated } \\
\text { readers }\end{array}$ & $\begin{array}{l}\text { Complete } \\
\text { disregard for } \\
\text { English } \\
\text { writing } \\
\text { conventions; } \\
\text { paper } \\
\text { illegible; } \\
\text { obvious } \\
\text { capitals } \\
\text { missing, no } \\
\text { margins, } \\
\text { severe } \\
\text { spelling } \\
\text { problems }\end{array}$ \\
\hline $\begin{array}{l}\text { 5. Style } \\
\text { and } \\
\text { quality } \\
\text { of } \\
\text { expressi } \\
\text { on }\end{array}$ & $\begin{array}{l}\text { Precise } \\
\text { vocabulary } \\
\text { usage; use of } \\
\text { parallel } \\
\text { structures; } \\
\text { concise; } \\
\text { register good }\end{array}$ & $\begin{array}{l}\text { Attempts } \\
\text { variety; good } \\
\text { vocabulary; not } \\
\text { wordy; register } \\
\text { OK; style fairly } \\
\text { concise }\end{array}$ & $\begin{array}{l}\text { Some } \\
\text { vocabulary } \\
\text { misused; } \\
\text { lacks } \\
\text { awareness of } \\
\text { register; may } \\
\text { be too wordy }\end{array}$ & $\begin{array}{l}\text { Poor expression } \\
\text { of ideas; } \\
\text { problems in } \\
\text { vocabulary; } \\
\text { lacks variety of } \\
\text { structure }\end{array}$ & $\begin{array}{l}\text { Inappropriat } \\
\text { e use of } \\
\text { vocabulary; } \\
\text { no concept } \\
\text { of register or } \\
\text { sentence } \\
\text { variety }\end{array}$ \\
\hline
\end{tabular}

Those aspects from two experts have been compared to meet the most suitable aspect that is used on this research. The writer assumed that the aspects from Brown and Bailey was more appropriate to apply on this research, for they serve the aspects and the assessment (analytic scoring) as well. However, since this research was only focused on the enhancement of a single paragraph, the writer limited some criteria or categories from them which dealt with the constructions of an essay.

\section{The Concept of ICT in Education}

Margaret states that ICT (information and communications technology - or technologies) is an umbrella that involves any communication device, tool or application. For example, radio, television, cellular phones, computer and network hardware and software, satellite systems and so on, as well as the several services and applications related to them, such as videoconferencing and distance learning. ${ }^{15}$

Moreover, ICTs are often spoken of in a particular context, such as ICTs in education, health care, or libraries. ICT in education means teaching and learning with ICT. Worldwide research ${ }^{16}$ has shown "ICT can lead to improved student learning and better teaching methods". A report made by the National Institute of Multimedia Education in Japan, proved that an increase in student exposure to educational ICT through curriculum

In sum, ICT in education is technology or device used to manage information and aid communication for the purpose of education. In addition, the use of ICT in education is not only to improve the effectiveness and quality of the learning and better teaching methods, but also more importantly to enhance the mastery of ICT for teacher and student as a life skill in the era of rapidly changing and progressing technology.

\section{The Concept of Internet-based Language Learning}

The findings of recent studies showed that online learning and instruction had positive impacts on language learning. For instance, Conroy ${ }^{17}$ concluded "Internet based or assisted language learning could

\footnotetext{
${ }^{15}$ Margaret Rouse. ICT (information and communications technology-or technologies)

http://searchcio.techtarget.com/definition/ICT-information-and-communications-technology-or-technologies. (Accessed July 02, 2014).

${ }^{16}$ UNESCO. 2013. ICT in Education. http://www.unesco.org/new/en/unesco/themes/icts/. (Accessed December01, 2013).

${ }^{17}$ Conroy M. A. 2010. Internet tools for language learning: University students taking control of their writing. Australasian Journal of Educational Technology, 26(6), 861-882. http://www.ascilite. org.au/ajet/ajet26/conroy.html(accessed November 12, 2012).
} 
support students in independent language learning and academic writing because these students were enthusiastic and reasonably competent users of Internet-based tools and techniques".

As pointed by Lee $\&$ Woods 18 "In this sense, web-based, technology-enhanced learning seem to be able to stimulate, and supported the learning process and enhanced learning outcomes." In addition to Conroy and Wang, Shih ${ }^{19}$ also gave a statement to the issue "Technology-enhanced learning through web pages supported learners by such ways as facilitating and providing feedback or assessment, thereby reducing the effort expended on organizational issues and improving learning effectiveness." Hence, the advantages of web-based features in teaching learning have been proved by many experts and researchers. However, the writer still needs to know what might happen to students' learning atmosphere when they use the web-based in Edmodo.

\section{Web-based Writing}

Web-based writing is a text created with (and usually intended for viewing on) a computer, smartphone, or similar digital device. It is also known as online writing. Online writing formats include texting, instant messaging, emailing, blogging, and posting comments on social media sites such as Facebook. ${ }^{20}$ Moreover, the technology that is getting enhanced becomes something important in teaching-learning activities. Many teachers use it to enhance their teaching method, strategy, and technique in order to achieve the teaching-learning goals. Brondou ${ }^{21}$ states "Students at all levels across the country are struggling to develop writing abilities, making some educators turn to Web-based programs for help"

\section{The concept of Edmodo}

Edmodo that became the aid in this research was created in late 2008 by Nic Borg and Jeff O'Hara. Nic and Jeff state ${ }^{22}$ "We realized that we needed to evolve our school environment to reflect the connected world in which we live. The two set out to create a tool that closed the gap between how students lived their lives and how they learnt in school." Furthermore, Edmodo itself is a free and secure social learning network for teachers, students and schools. Edmodo provides classrooms a safe and easy way to connect and collaborate, offering a real-time platform to exchange ideas, share content, and access homework, grades and school notices.

Moreover, the reasons of why the researcher chose Edmodo as a tool, aid, and strategy in this current study was because it gave the writer the option to create sub-groups or smaller groups within a group, it took very little effort for time-poor teachers and resource strap schools to get it set up. Also, Edmodo was remotely hosted (so the writer did not need extra equipment, software or tech support staff to run it), it was free of charge. Users interface were friendly and quick to learn. The low barrier-to-entry meant Edmodo actually got used to by students and teachers, at very low risk of wasting school time or money. In addition, Edmodo was more about communicating with the writer's class and managing basic class activities.

${ }^{18}$ Lee S. E. \& Woods K. J. 2010. Using contemporary topics and Internet resources to stimulate student-centred learning. Australasian Journal of Educational Technology,26(6),775-790.http://www .ascilite.org.au/ajet/ajet26/lee.html (accessed November12, 2012).

${ }^{19}$ Shih R. C. 2010. Blended learning using video-based blogs: Public speaking for English as second language students. Australasian Journal of Educational Technology, 26(6), 883-

897.http://www.ascilite.org.au/ajet/ajet26/shih.html(accessed November 12, 2012).

${ }^{20}$ Richard Nordquist. Grammar \& Composition Expert. http://grammar.about.com /od/mo/g/OnlineWriting.htm (accessed July 15, 2014).

${ }^{21}$ Brondou Colleen. 2010. Using Computer Programs to Improve Student Writing:Learning to Write in the $21_{\text {st }}$ Century.http://www.findingdulcinea.com/news/education /2010/march/Using Computer-Programs-toImprove-Student-Writing.html (accessed January 15, 2013).

${ }^{22}$ Borg \& O'Hara. 2011. 10 Reasons I Love Edmodo \& Recommend It For Educators.http: //adaptivelearnin.wordpress.com/2011/11/13/10-reasons-i-love-edmodorecommend-it-foreducators /(accessed December26, 2012). 
Hence, Edmodo is a free and secure social learning network for teachers, students and schools. It provides a safe and secure classrooms and easy way to connect and collaborate to exchange ideas, share content, and access homework, grades and school notices.

\section{The Advantage of Edmodo}

Moreover, there were some top tools and features of Edmodo that differ it from other social media, such as:

a. Teachers and students could collaborate in a secure, closed environment.

b. A message board allowed secure and open communication that could be monitored and controlled by the teacher.

c. It was easy to monitor student interaction.

d. Teachers could post assignments and assessments that were electronically submitted and automatically graded.

e. A built-in survey tool could be used to check for understanding (no clickers required).

f. Teachers and other school personnel could create professional groups, subject area communities, and other networks to extend professional development.

g. Teachers and students could store and share documents and files in a wide variety of formats in a cloud-based environment.

h. Teachers could maintain a personal content library and share content with members.

i. Students could instantly access their files $24 / 7$ through their cloud-based 'Library'.

j. Folder-sharing allowed teachers to share all content for particular units of study with select groups or all students.

k. Parents could create a parent account to connect with their child's groups.

1. User got cloud capabilities and convenience with airtight security.

$\mathrm{m}$. A brilliantly simple user interface - little or no formal training required

n. Edmodo was free - and free of ads. 55

\section{The Procedure of Edmodo in Teaching Writing}

There were several steps that had to be done by the researcher before he started the research (teaching writing) using Edmodo, they were creating an Edmodo account and creating a group.

\section{The Procedure of Edmodo in Teaching Writing}

There were some procedures that must be applied by the writer in Edmodo in order to meet the maximum outcomes and result. The procedures were as follow:

1. Post and give explanation or discussion through Edmodo

2. Post assignments into Edmodo daily

3. Check students' works on Edmodo

4. Give feedback to students' assignments through Edmodo

\section{The Concept of Extensive Learning}

The aim of extensive learning was to encourage learners to write daily writing in their non-school hours. Applying this way, the writer could get learners to do regular writing and extensive learning. In addition, the writer could organize a system where learners wrote a writing each day. Furthermore, the researcher read students' writing and then gave comment or feedback to their writing directly; however, when the researcher assumed that the student(s) did not need any feedback toward the discussion, he would not give it to them. In hence, teacher found that learners got into the habit of writing each day, and it meant that the students' writing skill improved over time. However, according to Educasia.org in their journal entitled Extensive Reading and Writing: Teacher's Guide there are some advantages of extensive learning, especially in writing, they are 
1. Learners can write by themselves, outside the classroom.

2. Learners practice using the language they know in a natural context.

3. Learners get opportunities to think about what they are doing and learning.

4. Learners can express their ideas, opinions and feelings.

5. Learners get exposure to language being used naturally.

6. Learners get exposure to new information and ideas.

7. It can be fun. ${ }^{23}$

Moreover, Lavin ${ }^{24}$ also suggested that "writing extensively, in which students write relatively large quantities of English, typically online, may be a good way to boost learners' total quantity of output and to improve fluency." In addition, as pointed by Dr. Sulzberger ${ }^{25}$ from the Victoria University of Wellington, New Zealand, he claims that people's brain required to learn and understand a new language, and it will develop and improve automatically from exposure(s) to the language. Then he came across to a simple answer, and it was extensive exposure to the language. Meanwhile, exposure refers to the interaction that the learner gets with the language that they are trying to learn, and it often refers to the interaction outside the classroom.

In sum, extensive learning is a learning, giving exposures or interactions to the learners which happens outside the classroom.

\section{RESEARCH METHOD}

\section{Research Design}

In conducting this research, the writer applied a qualitative approach. Through qualitative approach, the writer could obtain a fresh view of the data, could progress from initial description through the process of breaking data down into bits, and could see how these bits interconnected to a new account based on the writer's reconceptualization of the data. The writer broke down the data in order to classify it: the concepts which created or employed in classifying the data, the connections that had been made between these concepts, and finally provided the basis of a fresh description. Furthermore, the writer applied Educational Research and Development (R \& D) technique in investigating the use of Edmodo as a media to support the enhancement of students' paragraph writing skills to promoting the extensive learning on this current study. It was because the writer wanted to find out, to provide, and then to apply the best learning opportunities that students had.

Borg and $\mathrm{Gall}^{26}$ provide several steps or procedure that must be applied in order to meet the maximum requirements in this approach. The steps are 1. Research and information collecting, 2. Planning, 3. Develop preliminary form of product, 4. Preliminary field testing, 5. Main product revision, 6. Main field testing, 7. Operational product revision, 8. Operational field testing, 9. Final product revision and 10. Dissemination and implementation.

\section{Research Participants}

The participants to be researched in this study were the non-regular students of first semester of faculty of teacher training and education, majoring in English Education, STKIP Pancasakti, Tangerang. The students were graduations of public and private senior high school. The participants have studied English for twelve years since they were in elementary school. However, they have never been taught

\footnotetext{
${ }^{23}$ Extensive Reading and Writing: Teacher's Guide.http://educasia.org/wp-content/uploads /Educasia/20Myan/20page/ELT/Extensive/20Reading/20and/20Writing/20TB.pdf(accessed January 15, 2013).

${ }^{24}$ Richard S. Lavin. 2003. Dimensions of Extensive Writing. JALT2003, Shizuoka, Japan, 410.http://jalt-publications.org/archive/proceedings/2003/E074.pdf(accessed October 09, 2013).

${ }^{25}$ Sulzberger. 2009. New study may revolutionize language learning.http://www. stumbleupon.com/su/ 4nIuan\#(accessed March 14, 2014)

${ }^{26}$ Meredith D. Gall, Joyce P. Gall, Walter R. Borg. 2003. Educational Research. An introduction. USA: Pearson Education Inc. p. 775
} 
how to write an academic paragraph (English) comprehensively. Hence, their writing skill was still low. Furthermore, there were twenty five students at the first semester (11 male and 14 female), yet the writer only chose thirteen of them randomly as the resource of the data.

\section{Data Collecting Techniques}

In this section, the writer elaborated and visualized the data collection as a series of interconnected activities. Data collection was aimed to gather useful information to answer the research questions of the study. The steps of data collection is called the "cycle". It started from locating site or individual, acquiring access and making rapport, purposefully sampling, collecting data, recording information, resolving field issues, and storing data. The steps of data collection are as follows:

1. Locating site or individual. In this step, the writer was required to find people or places to explore or to be searched. The site of this study was at STKIP Pancasakti which was located in Tangerang.

2. Access and Rapport. This step was very essential to provide good data for the research. Suparman69"several steps to get access to the site were required, such as: permissions, need the accelerated or full review, and qualitative project description." However, because of the writer was a lecturer at that institution, the writer did not have to do all those things.

3. Purposeful Sampling Strategy. The purpose of this step was to make the writer had a clear idea in his mind and supplied the rationales for his decisions.

4. Forms of Data. The last step explained that there were several types of information to be collected in qualitative research. The types were as follows: observation, interview, documents, audio-visual materials, journaling in narrative storytelling, observing through videotapes, and photographs.

Furthermore, the writer also did some several steps in order to get more valuable and reliable data. Those steps were interview, observation, and documentation.

\section{Data Analysis}

The data of this research was gathered from students' activities and writing through Edmodo. Furthermore, in analyzing the data of the study, there were several steps that must be accomplished by the writer, they are Organizing, Decoding, Classifying data, reducing data, and Cross checking (Triangulation).

\section{RESULT AND DISCUSSION \\ Students' Writing Test}

Based on the data of pre-observation (students' writing test), it was found that the students had some difficulties in writing a paragraph academically: organization, content, grammar (sentence problem), punctuation, and style and quality of expression (vocabulary).

\section{Interview Based Data}

As mentioned in chapter three, interview is an important thing in collecting the data of the research, especially for the qualitative research. Moreover, the interview was held in two different occasions: first, the interview to get the preliminary data of the research, and it was held at the beginning of the research and the second one was the interview to get the information about the use of Edmodo as a media to support students' extensive learning, and it was held at the end of this research.

The first interview was to get the preliminary data of the research. The writer interviewed the participants in class privately, so that the writer could get the reliable information (answers) or data for the research. Moreover, the information contained in this interview will be elaborated in the next following explanation.

1. First is the grade. As written in the title of the research, the grade of the students or the participants was the first semester grade. 
2. Next is how the students prepare their writing class. Based on the data of the interview, the data informed that most of the students did not make any significant preparation(s) for their writing class

3. The books. Students argued that they had a book entitled "Fundamental of English Grammar" by Betty Schrampfer azar. It was the book about how to write a sentence(s) or tenses. Also, it was the only book they had in their writing class. On the other hand, the students did not have any other book to learn of how to write a paragraph.

4. How the lecturer evaluates their learning. Based on the data of the interview, most of the students answered that the assignment they received was rarely to have evaluation or discussion.

5. The condition of their writing class. Based on the data of the interview, many of the students stated that the class was not as interesting as the speaking class, they were easily to get stuck when they tried to make sentences (tenses), the class (lessons) is difficult, and sometimes they were easily to get bored when they were in writing class which those made the students felt uncomfortable during the lessons

6. How many hours of writing class do the students receive in a week. Based on the students' answers, the data informed that the students only received two hours a week for writing class, and it was on Sunday

7. Students stated that the internet was really helpful in finding the additional explanation of the lesson when they were in the classroom because they had limited sources

8. How they feel about the writing class. According to the students' answers, most of them stated that they were not motivated in their writing class and easily to get bored

9. Writing assignments. They usually received from the lecturer, most of the students argued that they were usually asked by the lecturer to make some sentences for some tenses at the end of their writing class

10. How writing interact them in class. Related to the question, most of the students stated that they found nothing that could interact them in writing class. However, when they felt stuck or did not know what to write, the only thing could help (attract) them was the internet.

11. Kind of exposure or exercise do the students usually do in their recess time. Based on the students' answers, it was found that most of the students were rarely to learn writing outside their class or in their recess time. They stated that they had no place to learn writing and they did not know what to learn .

The second interview was held to get the information of how Edmodo is used as a media to support the students' extensive learning. In other words, the information of the second interview could be used to support and strengthen the data from observation. Furthermore, the information contained in this interview were: the information of students' knowledge of Edmodo itself, what students' feel while they were using Edmodo, the difficulties in using Edmodo, the effectiveness of Edmodo as a media to support their extensive learning, and students' opinion about Edmodo as a media to support their extensive learning.

1. the information of students' knowledge of Edmodo itself. Based on the students' answers, it was stated that there was only one student who knew about the Edmodo at the first time, yet he never knew how to use it.

2. What the students feel while they were using Edmodo. The data informed that the students feel so safe and secure when they did and submit the assignments in Edmodo. They stated that they were free to express their ideas and writing because they knew that when they made mistakes, the lecturer would inform them. 
3. The difficulties. At the first phase (stage), there were two students who found difficulties in using Edmodo while I was explaining it in class. They stated that it was because they were not familiar with the terms in Edmodo. However, in next following observation (outside the classroom) those students were able to follow the directions, and they always submit the assignment on time.

4. students' opinion about Edmodo as a media to support their extensive learning. Although at the first phase (stage), there were two students who found difficulties in using Edmodo, yet at the end of the learning, all of the students stated that Edmodo did really work in helping them to learn English outside the classroom or in their home, especially in writing. They informed that learning through Edmodo was so safe; they could post their answers and no one knew about the answers (tasks).

\section{Observation Based Data}

The observation was conducted in two different places, they were when the students in classroom and while the students were using Edmodo as a media to support the extensive learning (in their recess time). In other words, the observation was gathered inside and outside the classroom.

Based on the data of the observation, it was found that Edmodo could be used to solve the problem of time limitation. It was proven by the additional time that students had in learning English, especially in writing through Edmodo. The procedure of the writer in using Edmodo as a media to support the extensive learning was by giving the students daily assignment. Daily assignment that was given to the students was aimed to make them got more exposures because they received insufficient time in learning how to write a paragraph and to make them becoming the autonomous learners at the end of the learning. The assignments they had submitted then checked by the writer. Furthermore, every time the students made mistake on their assignment, soon the writer gave them evaluation or feedback in Edmodo. In short, the writer observed the use of Edmodo through students' activities and progress using their assignments and works that they had submitted into Edmodo daily.

Furthermore, based on the data of the observation, the students seemed easily to learn English using Edmodo at the first time; it was proven by the time they submitted the assignment in time even though there were still some mistakes in their answers. Moreover, after the process in using Edmodo for days by the students, it could be seen that the students were getting familiar, easy, interact, and interested in using it as a media to support their learning each day. It was proven when they asked the writer to confirm and to find more related sources from other networks, and put them into Edmodo.

In addition, to make them more attracted and excited in writing, the writer also created the assignment in sequent pictures (picture qued) and video. It was because they were easily to get bored and stuck when they tried to make their writing and they do not know what to write. Also, the writer put some links into Edmodo related to the topic (lessons).

\section{Discussion}

\section{Factors influencing the students' inabilities to write an academic paragraph properly}

Based on the result of the study, it was found that there were several factors which influenced students' inabilities to write an academic paragraph properly. (1) "students' writing ability was low or poor," (2) "students had limited time in learning English," (3) "students felt uncomfortable in learning English," (4) "students were not motivated to learn English," (5) "students were lack of exposures," (6) "students got insufficient materials," (7) "students did not know how to start writing," and (8) "students are lack of feedback".

First, students' writing ability was low or poor. The data informed that most of the participants in this research had low ability in writing an academic paragraph properly. It was because they never 
had a chance to learn how to conduct or to write a paragraph academically when they were in the senior high school. Most of the students just learnt tenses and how to conduct a sentence(s).

Next was students had limited time in learning English. The university only gave two hours a week to learn how to write in English. Meanwhile, for human, several hours a week is not enough to learn a language. Since, the language that was being learned was a foreign language, it would be more difficult, more procedures, and more time for students (adults) to acquire that language. Krashen ${ }^{27}$ recognizes "adults have two different ways to develop competence in a language: language acquisition and language learning". First is Language acquisition. In other book, Dulay et al also claim Language acquisition is a subconscious process not unlike the way a child learns language. Language acquirers are not consciously aware of the grammatical rules of the language, but rather develop a feel for correctness. In non-technical language, acquisition is picking-up a language. ${ }^{28}$ The other one is Language learning. Language learning refers to Brown80 is the "conscious knowledge of a second language, knowing the rules, being aware of them, and being able to talk about them." Thus language learning can be compared to learning about a language. In other words, the length of the process of human in acquiring language is not something that can be achieved in hours. So that, in this case, the extensive learning (learning outside the classroom) was really suitable for them, since they only received two to four hours per week to learn writing.

Moreover, the third factor was students felt uncomfortable in learning English. From the data of the research, it was obviously seen that they were easily got bored in class when they were studying English especially for writing class. Nevertheless, the factor was because the subject was so tedious which led to the uncomfortable environment. However, when students felt uncomfortable in their learning, they wouldn't respond well to the teacher and the material or they just sit still in a chair for six hours per day and acquired nothing. In other words, students learnt nothing. Mc Robbie at all ${ }^{29}$ define "the nature of the Classroom Learning Environment and psycho-social interactions can make a difference in how the students learn and achieve their goals". It is because, most of the learning process takes place there. They learn through exploration and discovery using their senses to support their natural curiosity and desire to learn. Providing the feeling of security and pleasure. If the student feels uncomfortable of the classroom conditions, then they will have less concentration on the lesson and so they get a little information only.

Furthermore, the fourth problem was students were not motivated to learn English. In line with the third problem, it was found that the reason of why students were not motivated in their learning was because of the tedious subject, for they only had one book to learn writing. In addition, most of the teachers or lecturers only ask the students to do task that was printed in text book. In line with the previous explanation, Stephen Krashen argued that the teachers should use authentic materials. For example, feature movies, newspapers and magazines, and popular fiction, rather than the ESL textbooks and the like. It was because boredom could be reduced likely with these authentic materials, since they were the kinds of things that common people enjoyed in real life $\mathrm{e}^{30}$

The fifth problem was students were lack of exposures. In accordance to the problem of limited time in learning English, especially for writing, many students got insufficient exposures to the discussion because of the limited time. It seemed that they only practiced and had exposures in writing when they were in classroom, yet outside the classroom they did not have any significance exposures that could make them kept practicing on the discussion; meanwhile, writing is difficult process to learn

\footnotetext{
${ }^{27}$ Stephen D. Krashen. 1981. Second Language Acquisition and Second Language Learning. California: Pergamon Press Inc. P. 1-2

${ }^{28}$ Dulay Heidi, Marina Burt and Stephen Krashen. 1982. Language Two. New York: OUP.

${ }^{29}$ McRobbie, C.J., Roth, M.W., \& Lucas, K.B. 1997. Multiple learning environments in a physics classroom. International Journal of Educational Research, 27, 333-342.

${ }^{30} \mathrm{Krashen}$, loc.cit.
} 
and a hard skill to teach. As we have known, writing needs a lot of practices and exposures for someone in order to be able to write in English. As pointed by Dr. Sulzberger from the Victoria University of Wellington, New Zealand, he claims that our brain required to learn and understand a new language, and it will develop and improve automatically from exposure(s) to the language. Then he came across a simple answer: extensive exposure to the language. ${ }^{31}$

In addition to five problems above, another problem that occurred from the data of the research was the insufficient materials that students had. In some schools, the textbook becomes the most important source. United Nations Educational, Scientific and Cultural Organization (UNESCO) ${ }^{32}$ writes "without the textbook, skills, concepts and content required by the curriculum cannot be taught". In the absence of any other widely available sources of information, the textbook also becomes the most important and often the only source of content and pedagogic information for the teacher. However, in this university (class) they only had one textbook for their writing class, it was a book about tenses and grammar, and it was not a book to learn how to write a paragraph. Furthermore, based on the data of the research, it seemed that the students found some difficulties to learn English due to the insufficient learning resources they had. As the result, the writer put some materials related to the lessons in Edmodo through the feature called library. This feature possible the students to access the material 24 hours a day.

The seventh problem was students did not know how to start writing. People know that to write something is a big task, yet to start writing is the hardest part. Based on the data of the research, it was found that the reason of why students did not know how to start writing was because they were lack of ideas and because of the condition or situation in the classroom which did not support them to start writing. As pointed in the previous problem, to make the students interested and had more ideas, the writer gave some sequent pictures (picture qued) and videos in Edmodo. As the result, it seemed that the students got more ideas in writing a paragraph.

The last problem that appeared from the data of the research was lack of feedback. Many students complained that the lecturer was rarely evaluate their assignments, or sometimes, they have never had the feedback or discussion towards the task or the discussion they had learnt or had worked at all. The lack of feedback could be crucial especially in writing because they needed to know what kind of mistakes they had made and how to fix them. In line with the words, Centre for Development of Teaching and Learning (CDTL), National University of Singapore ${ }^{33}$ argues "It is important for students to know how well they are doing as they learn." The theories also supported by Gibbs and Simpson $^{34}$, they argue "feedback on performance is so important; feedback to the students on their assignments was the single most powerful influence on student achievement".

In sum, there were several factors that caused the students unable to write a paragraph academically: students had limited time in learning English, students felt uncomfortable in learning English, students were not motivated to learn English, students were lack of exposures, students got insufficient materials, students did not know how to start writing and students are lack of feedback.

\footnotetext{
${ }^{31}$ Sulzberger, loc.cit.

${ }^{32}$ UNESCO. Basic Learning Material: chapter 4.http://www.unesco.org/education/blm/ chap4en. php(accessed March 14, 2014)

${ }^{33}$ Students Learn Well by Doing http://www.cdtl.nus.edu.sg/ideas/iot407.htm CDTL 2000 - 2008 Volume 1 february 2003 acc

${ }^{34}$ Graham Gibbs \& Claire Simpson. 2004. Learning and Teaching in Higher Education, Issue 1, 2004 05: Conditions Under Which Assessment Supports Students' Learning. Oxford University, Open University, UK p. 17-19
} 


\section{How to use Edmodo to solve the problem of time limitation}

As mentioned in the findings, in solving the problem of time limitation, Edmodo has some advantages features, they are the access of files $24 / 7$ through the cloud-based 'Library' and foldersharing.

First is the access of files 24/7 through the cloud-based 'Library'. Based on the result of the study, it was found that the students had insufficient time in learning English when they were in class, especially for writing; commonly, the students had about two hours a week to learn writing in class. However, the feature of Edmodo offered the access of files 24/7 through the cloud-based 'Library'. In this research, students usually visited the library when they were in recess time or at home, using their phone, laptop or computer.

The other feature of Edmodo in solving the problem of limited time is folder-sharing. Folder-sharing is a feature in Edmodo that allows lecturer to share all contents for particular units of study with selected groups or all students. This feature possibly the lecturer to put all the materials and sources into a specific folder. The folder(s) that had been put into Edmodo would not disappear or difficult to find because Edmodo has specific place for this feature. On the other hand, lecturer could have folder as many as he wanted, and it consisted of many learning materials.

Moreover, based on the previous studies, there are two researchers who give similar theories and findings toward the discussion, they are Thaha and Monica. Thaha ${ }^{35}$ states "learning through web 2.0 (which happens outside the classroom) can give additional information through discussions and exchange of information to students". In other words, learning outside the classroom (extensive learning) or in their recess time does really help students in solving the problem of limitation. In addition, Monica ${ }^{36}$ states "it is time to move on and make use of the technologies that can create collaboration similar to those in the physical environment". Monica realizes that learning through social media can give similar effects on students' performance, and it can be used to enhance students' quality time in learning.

\section{How to use Edmodo to improve students' writing motivation}

In improving students' motivation in writing a paragraph, Edmodo has an interesting feature; it is cloud-based environment. Cloud-based environment is a feature that allows students and teacher to visit any link or web they want to visit or available on Edmodo itself, and to post any picture and video they have. The link itself could be saved by the lecturer or students (by the permission of the lecturer) in the library or in students' profile, and it was available to read for 24 hours a day.

Undeniably, sometimes students did not know what to write when their lecturer asked them to write a paragraph; hence, students got bored easily, yet this feature possibly lecturer to post pictures or videos, and used them in Edmodo as a media or tool to enhance students' motivation in writing a paragraph. The objective of using this kind of method was to assess students' writing ability responses to the appropriate context or to stimulate students' responses.

According to stempleksi ${ }^{37}$ "lesson with video should be enjoyable and should provide even mediocre students with a genuine sense of achievement". It means that teaching through audio visual can make the students feel their interest quicken when language is experienced in a lively way. So that, the combination of moving pictures and sound can present language more comprehensively and more realistically than any other teaching medium.

\footnotetext{
${ }^{35}$ Thaha, loc.cit.

${ }^{36}$ Monica, loc. cit.

${ }^{37}$ Stempleksi, loc.cit.
} 
Thus, the use of pictures and video as media to support the teaching-learning in Edmodo were able to improve students' motivation. Hence, the features could improve students' writing skills eventually.

\section{How to use Edmodo to expose the students in writing paragraph academically}

In giving exposures to students, Edmodo has some advantages characteristics, they are teachers can post assignments that are electronically submitted, a built-in survey tool can be used to check for understanding, teachers and other school personnel can create professional groups, and teachers can maintain a personal content library and share content with members.

However, the lesson, the explanation, and the assignment that was given to students as the exposures was given step by step, and those were based on Oshima and Hougue's book, Academic writing. The exposures was started from the types of sentences, (simple sentence, compound sentence, complex sentence, and compound-complex sentence), next, the constructions of an academic paragraph (topic sentence, supporting sentence, and concluding sentence), and the last was the aspects of writing (organization, content, grammar, punctuation, and style and quality of expression). As pointed by Dr. Sulzberger from the Victoria University of Wellington, New Zealand, he claimed that our brain required to learn and understand a new language, and it would develop and improve automatically from exposure(s) to that language. Then he came across a simple answer: extensive exposure to the language. Meanwhile, exposure refers to the interaction that the learner gets with the language that they are trying to learn, and it often refers to the interaction outside the classroom ${ }^{38}$.

\section{How to use Edmodo to provide feedback}

In providing feedback, Edmodo has some advantages characteristics, they are teachers and students can collaborate in a secure and closed environment or group, a message board allows secure and open communication that can be monitored and controlled by the teacher, and a built-in survey tool that can be used to check for understanding. However, those characteristics are included and compiled in one feature; it is small group.

As we have known, there were some students who had different level of affective filter. So that in giving feedback, lecturer must know and consider about his affective filter or his psychological aspect, so students would not feel shame or afraid in posting their answers. According to Krashen affective Filter is the term that refer to the several of negative responsive or emotional and motivational factors that may affect the reception and processing of comprehensible input. For example, anxiety, self-consciousness, boredom, annoyance, alienation, and so on. ${ }^{39}$

In addition, he also mentions some ways to maintain the affective filters, there are as follows: 1 . we do not test students on the material they are working with. This will eliminate the main source of anxiety, 2. we do not require students to perform when they are not ready and willing to do so, 3 . we use authentic materials -- feature movies, newspapers and magazines, popular fiction, etc. -- rather than ESL textbooks and the like, 4. we do not use exercises, drills, or any kind of artificial task that has no ostensible or sensible purpose other than language practice. Instead, we maintain a flow of ordinary, meaningful language about people, places, things, ideas, stories, and so on, 5. teachers function as partners and mentors (positive roles) but not as testers and judges (negative roles), 6 . frequent placement testing (see below) enables us to keep students in groups that reflect their current needs and abilities, and 7. I also admitted to any mistakes I made in class or let them know that I had to go home or talk to another teacher to get answers or ideas for class.

In short, in giving feedback to the students, teachers or lecturers must notice that not all of the students have same level of the affective filter; they are different psychologically.

\footnotetext{
${ }^{38}$ Sulzberger, loc.cit.

${ }^{39} \mathrm{Krashen}$, loc.cit.
} 


\section{CONCLUSIONS AND SUGGESTIONS}

\section{Conclusions}

The conclusions of this research will be served in five major points, as stated in the research questions, they are factors influencing students' inabilities to write an academic paragraph properly, how to use Edmodo to solve the problem of time limitation, how to use Edmodo to improve students' writing motivation, how to use Edmodo to expose the students in writing paragraph, and how to use Edmodo to provide feedback.

\section{Factors influencing students' inabilities to write an academic paragraph properly}

Based on the results of the data analysis and discussion in chapter four, it can be concluded that there were several factors which influenced students' inabilities to write an academic paragraph properly, they were students had limited time in learning English, students felt uncomfortable in learning English, students were not motivated to learn English, students were lack of exposures, students got insufficient materials, students did not know how to start writing and students were lack of feedback.

\section{How to use Edmodo to solve the problem of time limitation}

The use of Edmodo as a media to support the enhancement of students' paragraph writing skills seemed useful. It is proven by the solutions that Edmodo served in solving the problems of the research: solving the problems of time limitation. In this part, Edmodo had some advantages features, they were the access of files 24/7 through the cloud-based 'Library' and folder-sharing. Those features allowed lecturer to share all contents for particular units of study with selected groups or all students, and students could access the library and folders easily for 24 hours as long as they had permission from the lecturer. However, those features and solution could be reached and accomplished because of the characteristic of the social network itself: the 24 hours a day access from everywhere.

\section{How to use Edmodo to improve students' writing motivation}

Based on the results of the data analysis and discussion, improving students' writing motivation could be achieved through Edmodo as a media to support the teaching learning activities. At this section, Edmodo had an interesting feature to use; it was cloud-based environment. Cloud-based environment was a feature that allowed students and teacher to visit any link or web they wanted to visit or available on Edmodo itself and to post any picture and video they had. The link itself could be saved by the lecturer or students (by the permission of the lecturer) in the library or in students' profile, and it would be available to read for 24 hours a day.

\section{How to use Edmodo to expose the students in writing paragraph}

Related to the result of the data analysis, Edmodo proved that this features could be used as a media to support the teaching learning activities in giving exposures to students. For this point, Edmodo had some advantages characteristics to use, they were teachers could post assignments that are electronically submitted, a built-in survey tool that could be used to check for understanding, teachers and other school personnel could create professional groups and last, teachers could maintain a personal content library and share content with members. Furthermore, those advantages were used daily by the writer to give students exposure outside the classroom or in their recess time.

\section{How to use Edmodo to provide feedback}

At this section, based on the result of the data analysis, Edmodo had also some advantages characteristics in providing feedback to the students, and they were teachers and students could collaborate in a secure and closed environment or group. A message board allowed secure and open communication that could be monitored and controlled by the teacher, and a built-in survey tool that could be used to check for understanding. Amazingly, those characteristics were included and compiled in one feature; it was small group. In other word, the writer used this feature in Edmodo to provide the students feedback. 


\section{Suggestions}

In line with the conclusions, the writer also give suggestions based on those five major points, they are factors influencing students' inabilities to write an academic paragraph properly, how to use Edmodo to solve the problem of time limitation, how to use Edmodo to improve students' writing motivation, how to use Edmodo to expose the students in writing paragraph, and how to use Edmodo to provide feedback.

\section{Factors influencing students' inabilities to write an academic paragraph properly}

Related to the conclusion about the factors influencing students' inabilities to write an academic paragraph properly, the writer suggests that either the university or the lecturers, they have to be more careful in understanding their students: what students' needs and what may hinder them in teaching learning process. In addition, it will be better for the lecturer to hold a need analysis at the beginning of the semester, so they know what to teach or to give (not too difficult and not too easy for the students).

\section{How to use Edmodo to solve the problem of time limitation}

Given the conclusions of how to use Edmodo in solving the problem of time limitation, the writer suggests that lecturer must give the students additional time outside their classroom (recess time), so they will have more time to learn the subject. At this point, the lecturer can give the solution to solve this problem through social media, for its benefits. The lecturer can give the additional time outside the classroom or in the students' recess time, or it is commonly known as extensive learning.

\section{How to use Edmodo to improve students' writing motivation}

Based on the conclusions of how to use Edmodo to improve students' writing motivation, the writer suggests that a lecturer should use interesting and attractive materials to students, so he can engage students' motivation and attention while they are in the learning process. Moreover, those can be reached through Edmodo or technology at present days.

\section{How to use Edmodo to expose the students in writing paragraph}

In line with the conclusions of how to use Edmodo to expose the students in writing paragraph, the writer suggests that the lecturer should give extra attention(s) to the students: assignment and explanation of the current material(s) outside the classroom. It is because the students acquire insufficient knowledge (understanding and practices) of the language they learn. However, the lecturer can use Edmodo as a media to support the teaching learning process because it offers features and characteristics to make it happens.

\section{How to use Edmodo to provide feedback}

As pointed in conclusion of how to use Edmodo to provide feedback, the writer suggests that lecturer should really give evaluation towards the discussion and materials; however, a lecturer must consider students' affective filter (psychologically) in giving feedback because they are different psychologically

\section{BIBLIOGRAPHY}

Adhihari, A. Universities must rethink heir approach to student digital literacy. The Guardian(2010). http://www.guardian.co.uk/higher-education-network/higher-education-networkblog/2011/oct/10/digital-literacy-collaboration? CMP=twtgu. (accessed October 15, 2012).

Amanda Morin.4 Types of Writing Style(2013). http://childparenting.about.com/od/schoollearning/. (accessed December 01, 2013).

Blackstone, B., \& Harwood, C. Pedagogical blogging for university courses. Global Perspectives, Local Initiatives: Reflections and Practice in ELT (Selected Papers from the Third CELC Symposium for English Language Teachers), Center for English Language Communication, 
National University of Sigapore(2011). http://blog.nus.edu.sg/eltwo/2012/03/03/ usingfacebook-to-extend-learning-into-students-digital-lives/. (accessed October 15, 2012)

Borg \& O'Hara. 10 Reasons I Love Edmodo \& Recommend It For Educators(2011). http://adaptivelearnin.wordpress.com/2011/11/13/10-reasons-i-love-edmodo-recommend-itfor-educators/(accessed December 26, 2012).

Brace, Ian. Questionnaire Design: How to plan, structure, and write survey material for effective market research. London: Kogan Page Ltd, 2004.

Brondou, Colleen. Using Computer Programs to Improve Student Writing: Learning to Write in the 21st Century(2010). http://www. findingdulcinea. com/news/education/2010/march/UsingComputer-Programs-to-Improve-Student-Writing .html(accessed January 15, 2013).

Brown, Henry D. Principles of Language Learning and Teaching. 4th ed. New York: Longman, 2002. Buescher, Eileen. The Wonders of Educational Blogging(2010). http://coe.winthrop .edu/jonesmg/LTI/2010Fwhitepapers/Eileen_Buescher.pdf(accessed April 24, 2013).

Chomsky, N. Language Acquisition Device(1965). http://social.jrank.org/pages /353/LanguageAcquisition-Device.html\#ixzz2hCxdrzfE(accessed October 09, 2013).

Clark, R., \& Ivanic, R. Consciousness-raising about the writing process. In C. Candlin (Gen. Ed.), C. James \& P. Garrett (Eds.), Language awareness in the classroom. New York: Longman, Inc, 1991.

Conroy, M. A. Internet tools for language learning: University students taking control of their writing(2010). Australasian Journal of Educational Technology. http://www.ascilite.org.au/ajet/ajet26/conroy.html(accessed November 12, 2012).

Creswell, J. W., \& Urbom, J. Validity (verification) in qualitatitve research: Perspectives, terms, procedures, and methodologies. Unpublished manuscript, Department of Educational Psychological Psychology, University of Nebraska-Lincoln, 1997.

Creswell, J. W. Qualitative inquiry \& research design: Choosing among five approaches (2nd ed.), 2007.

Dulay, Heidi, Marina Burt and Stephen Krashen. Language Two. New York: OUP, 1982.

Elmoteam. What is ICT in Education(2013). http://www.elmoglobal.com/en/html/ ict/01.aspx. (Accessed December 01, 2013).

F. Scott Walters. (2000). http://lrs.ed.uiuc.edu/students/fwalters/para.html. (Accessed October 18, 2013).

Gall, Meredith D, Joyce P. Gall, Walter R. Borg. Educational Research. An introduction(7th Edition). USA: Pearson Education Inc, 2003.

Gall, Meredith D, Joyce P. Gall, Walter R. Borg. Educational Research: An Introduction (4th Edition). New York: LONGMAN, 1983.

Graham Gibbs \& Claire Simpson. Learning and Teaching in Higher Education, Issue 1, 2004-05: Conditions Under Which Assessment Supports Students' Learning. Oxford University, Open University, UK, 2004.

Graham, Steve\& Perin, Dolores.Writing Next: Effective Strategies to Improve Writing of Adolescents in Middle and High Schools(2007). http://www.all4ed.org /files/writingNext.pdf(accessed April 23, 2013).

Harwood, Chris \&Blackstone, Brad. Using Facebook to Extend Learning into Students' Digital Lives(2012). http://blog.nus.edu.sg/eltwo/2012/03/03/ using-facebook-to-extend-learning-intostudents'-digital-lives/(accessed December 25, 2012).

Hayashi, K. The effectiveness of video listening and one-sentence translation exercises on EFL student writing. Teaching Writing College and Universities Practical Reports, 5, 19-31. Writing Research Group, JACET Kansai Chapter, 2003. 